\title{
The role of Aggregators in DSM in the context of Business Digitization
}

\author{
András PUSKÁS-TOMPOS \\ The Bucharest University of Economic Studies, Bucharest, Romania \\ apuskas@yahoo.com \\ Adrian TANTAU \\ The Bucharest University of Economic Studies, Bucharest, Romania \\ atantau@fabiz.ase.ro
}

\begin{abstract}
Nowadays electricity trading and supply are evolving rapidly due to the digitalization of the electricity industry. This evolution is also generated by the development of many new business models in the field and also by new technologies in the form of smart meters, smart grids, smart homes, demand response, artificial intelligence, peer-to-peer trading, Internet of Things or Blockchain. All these technologies together have a huge contribution to the field of electricity and jointly create the digitalization of the electricity generation, transportation, supply and trading.

The aim of the research paper is to determine the degree to which consumers agree to work with an Aggregator to implement demand response. In addition, we have an interest in searching what makes them more attractive to electricity prosumers and consumers (both households and industry) as well as identifying those triggers which make electricity consumers or prosumers to start utilizing them.

We have to bear in mind that Demand Side Management besides offering incentives and monetary benefits also assists end consumers and prosumers in energy management in the meaning of decreasing energy wastes and increasing the level of optimal generation and consumption. Beyond the above mentioned facts, the focus is on the decrease of carbon dioxide emissions generated by pollutant fossil fuel electricity generation and positively affecting global warming, without endangering the proper functioning of electricity systems. Education and awareness have a huge role in achieving a more rational, optimal and conscious consumption of electricity through Demand Side Management. The issue has to be raised to the level of importance and acceptance similar to what recycling of other recyclable materials have nowadays, such as paper, plastic, various metals and glass.
\end{abstract}

Keywords: demand response, aggregator, smart meters, energy trading and supply, Internet of Things.

\section{Introduction}

In recent years the evolution of electricity smart meters and the dynamics with which they were installed pushed forward and supported profoundly Demand Side Management (DSM) to pass through very powerful development and evolution.

Nowadays in the electricity industry we can observe different types of challenges such as high energy losses, low efficiency and high emissions issues. Since there are differences between retail and wholesale prices, and also for the reason of flat electricity traditional prices there is no incentive for end consumers to modify or fine-tune their electricity consumption to supply costs. Demand side management has two big roles in the energy field. The first role is highlighted through the optimization of what it offers to the evolution, innovation and modernization of electricity markets, aiding the process of electricity generation, consumption, transportation or even storage. The second role - which is even more important than the first one - is when demand side 
management is offering solutions in the decrease of carbon dioxide emissions generated by pollutant fossil fuel electricity generation and positively affecting global warming.

A very efficient strategy for dealing with all of the above mentioned challenges in power systems is to utilize demand side management programs. Demand side management offers all the necessary instruments concerning the improvement of the features of a power system from the demand side. It can be classified in two sub-categories as Energy Efficiency programs and Demand Response (DR) programs. We can describe demand response as modifications made by the electricity consumers in their usual electricity consumption patterns as a response to receiving incentives and to electricity price fluctuations over time. Incentives are mostly offered in order to increase electricity consumption when prices are low and decrease their consumption when electricity prices are expensive (electricity price behaves in the same way as any other commodity price, driven by the demand and supply curves), but all these also for the proper functioning of the electricity systems (Jordehi, 2019).

In order for electricity end consumers to be able to use demand response, the electricity distribution industry should be digitized as much as possible, because all component parts of energy supply, distribution, trading, generation and storage should be well coordinated in real time. This can be done with the help of smart meters, artificial intelligence, machine learning, huge data storage and analytics, as well as fast transmission of these. For the reason that electricity is produced as much as it consumes in a given timeframe and its storage can be expensive, it is a slightly different commodity from the rest of the same category.

Digital technologies have become parts of our modern lives that are affecting most domains and through digitalization we will be able to improve sustainability, productivity, efficiency and safety of energy systems worldwide, taking into consideration questions of privacy and security. There is a continuous growth in the application of information and communications technologies (ICT) across energy systems, which can be identified as the digitalization of energy systems. The increasing convergence and interaction between the physical and digital worlds can be a different definition of digitalization. Three main elements define the digital world. The first element is digital information or the data. The second element is analytics - when using data we can create useful insights and information (Vrânceanu et al., 2020). The third element is connectivity through which the exchange of data between humans, machines and devices is made. As these three elements develop and advance, the trend to a greater digitalization is enabled. The evolution of these elements is a result of declining costs of data storage and sensors, more efficient machine learning, better connectivity of devices and people, cheaper and faster data transmission. "Internet of Things" (IoT), artificial intelligence and the Fourth Industrial Revolution are a range of concepts, trends and digital technologies contained in digitalization. Looking back from 2017 it can be expressed that in the previous two years $90 \%$ of the data in the world were created and during recent years' investments concerning digital electricity software and infrastructure has been increasing by $20 \%$ annually (International Energy Agency, 2017).

Until we have achieved the current utilization and acceptance of new technologies in the field of electricity distribution, supply and trading as smart meters, demand response, peer-to-peer trading, blockchain and artificial intelligence, the industry had to pass through several changes during the years. The Council of the European Union (EU) together with the European Parliament had to adopt a succession of law packages in order to reach the modern electricity trading of today.

Members States and EU came to a decision to gradually open these markets in the direction of free competition. In 1996 was adopted the First Energy Package for electricity and in 1998 for gas, the Second Energy Package was adopted in 2003. At this time the electricity supply could be 
made by a larger number of companies, households and industrial consumers were able to freely choose their electricity supplier. The Third Energy Package which helped future liberalization of internal electricity and natural gas markets was adopted in April 2009. The electricity market rules from the Fourth Energy Package, from June 2019, offer support to attract investments and on renewable energy (European Parliament, 2020).

As a short review, security of supply, free access to electricity networks, transparency and free competition were the main focal points of the first package. The mandatory establishment of National Energy Regulators and the separation of the medium and low voltage from high voltage electrical networks (the separation of the transmission from distribution) were in the centre of the second package. Internal electricity and natural gas markets, competition, harmonizing the power of independent Regulators from different countries, better cross-border regulation, more efficient transparency, separating supply and production activities from transmission and distribution operations (so-called Ownership Unbundling) have particular attention in the third package (European Commission, 2019). Figure 1 below shows how developed classic electricity markets work in the EU.

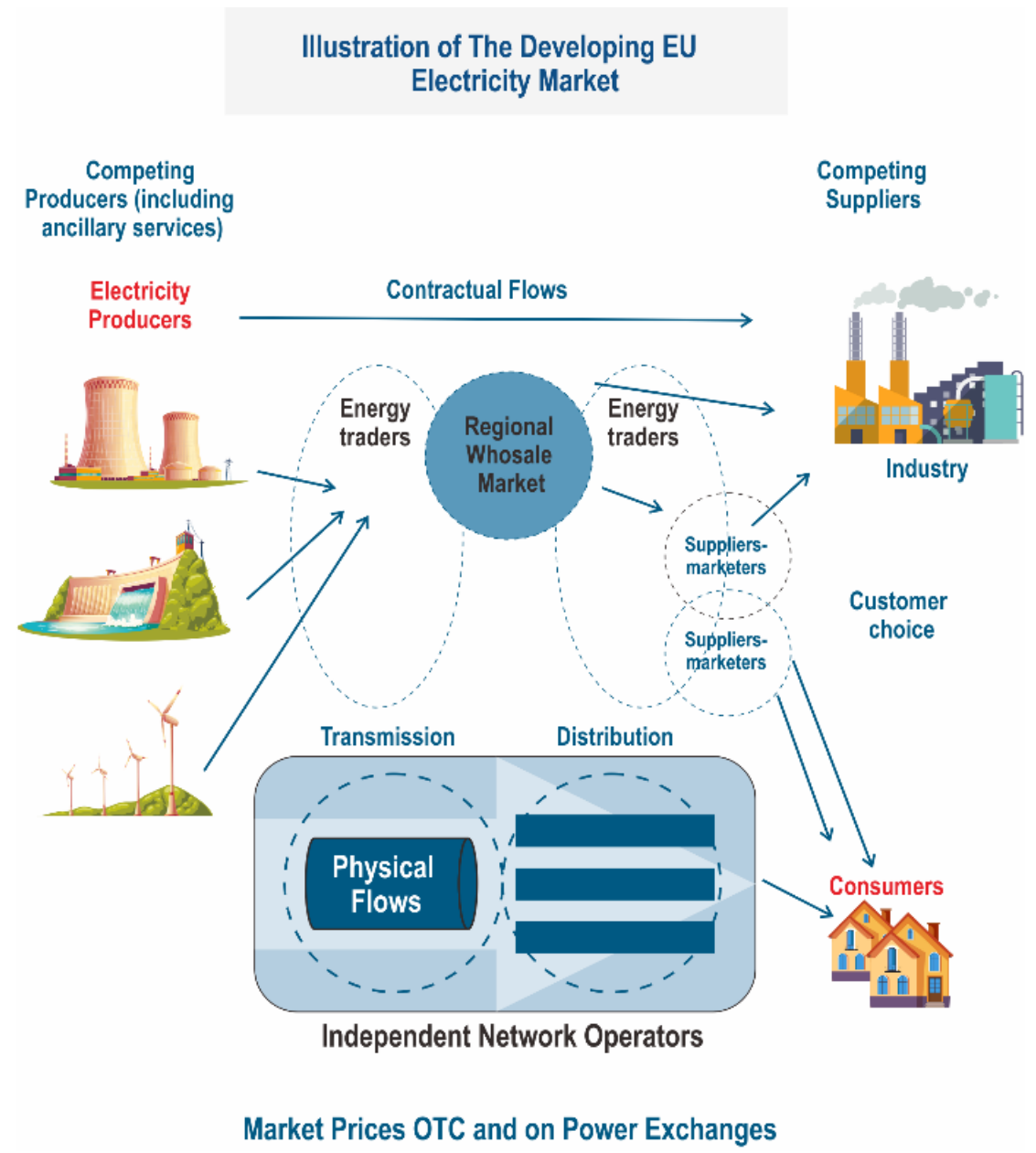

Figure 1. Illustration of the developing EU electricity market

Source: Adapted from Towards a single European energy market, EFET 15 years Edition, 2012, page 4: https://www. efet.org/Files/Documents/Energy\%20Background/Highlights-II-Final.pdf. 
The objective of the research is to determine the degree to which consumers agree to work with an Aggregator to implement demand response. In addition, we have an interest to search what determines them more attractive to electricity prosumers and consumers (both households and industry) as well as identifying the set off which make electricity consumers or prosumers start to take advantage of them. End consumers find it hard to learn how to work with these new technologies and their utilization creates difficulties, making them difficult to change from the convenient classic electricity supply (in the purchase of electricity), regardless of the time of consumption with fixed price to new models of optimized electricity consumption, even if this leads to an additional financial benefit. Furthermore, beyond these benefits, the increase of awareness regarding more rational, optimal and conscious electricity consumption, but also final consumer education is in the centre of attention. The outcome will be the reduction of pollutant fossil fuel electricity generation, lower carbon dioxide emissions and a more optimal use of renewable energy all these without endangering the proper functioning of the electricity systems.

\section{Literature review}

Because of the fact that demand response is voluntary, electricity consumers and prosumers should be convinced to participate. Participation in these programs means to accept home automation, to predictably respond to price signals, to participate in predictable and planned household activities that facilitate this kind of programs, this is also what modellers and analysts expect. As we have mentioned before, we would like to research the fact that end consumers are more attracted to DR through an aggregator (or Resource Aggregator) than participating by themselves.

\section{Definition of aggregator in the scientific literature}

The role of the aggregator as a market participant includes the following activities starting with registration and communication with consumers, calculation of consumption and savings, real time metering and forwarding of these data, calculation of user participation based on consumption and metered data. Furthermore, implementations of standards regarding metering and consumption verification, implementation of standards for data security, in the end consumer compensation. The aggregator, in addition to above mentioned, should obey local regulations and comply with the particularities of the local electricity market where he operates. (Radenkovic et al., 2020)

A different approach for the aggregator as resource aggregator, defines it as an intermediary company between distributed energy providers, electricity end-users and participants to the power system, which wants to utilize these services. According to the different types of resources it allocates, different types of aggregators exist. The role of demand aggregator collects DR resources of all end consumers, load aggregator accumulates the load flexibility of residential end consumers and production aggregator gathers small generators as virtual power plant works (Lu et al., 2020).

An interesting recent study describes the operational model called day-ahead dynamic pricing-based DR. The core of this model is that each night end consumers receive dynamic electricity prices for the next day, from different aggregators. Each aggregator has a different pricing scheme (dynamic pricing scheme), prices calculated in order to optimize its smart grid's total profit. The next morning the consumer can choose from these offers and pick which aggregator it works with (Tsao et al., 2021).

Analysing the resources that manage an aggregator can be classified in consuming resources (CL), producing resources (DG) and bi-directional resources (ESS). Consuming resources (CL) describes those loads which have a certain flexibility, even if traditionally they are considered differently. These flexible loads could be aggregated and provide various 
configurations of ancillary services. Producing resources (DG) usually contains renewable electricity generation, as well as small traditional generation units which are installed close to end users. These production units could provide emergency power supply. Bi-directional resources (ESS) contain movable energy storage devices and static energy storage devices, which will represent a very important part of future power systems operation. Aggregators' relation with end consumers can be classified in analysing customers' DR potential, scheduling ahead of time, installing control and communication equipment, and providing economic incentives to customers. Analysing customers' DR potential is necessary in order that the aggregator could offer a customized service for a given end consumer and could correctly evaluate its profitability. It is important to find out for each end consumer which factors are influencing its responsiveness. Scheduling ahead of time describes the action of informing end consumers about possible interruptions or about when they have to reduce their electricity consumption. Installing control and communication equipment necessary for implementing DR and for the interaction between end consumers and aggregators. The control and communication is made through different types of devices, which can also be smart meters with load control. The aggregator makes installation and maintenance of these equipment. It also provides economic incentives to customers through incentives or price reductions. These financial motivations and their level can attract end users to active participation in DR programs (Lu et al., 2020).

\section{Adoption of IoT technologies in the process of energy supply}

Internet of Things (IoT) or smart devices define those objects and devices, which are connected to the internet. These Things which can send and receive data include smartphones, home assistants, cars, smartwatches, home security, appliances and many other similar gadgets (U.S. Department of Commerce, 2019).

IoT is based on the fact that people and devices are connected to the internet. These devices collect, generate, exchange and process very large amounts of data. IoT has become a very popular topic in many fields of matter such as network technology, computational science, embedded systems and in many other areas. IoT has influenced various industries, including also the electricity industry. The progress in the field of IoT itself and also that of electricity generation has led us to the emergence of the field of Internet of Energy (IoE). IoE is described as all linked energy sources from a given grid connected through the internet, by which electricity distribution, storage and generation are kept under control in a smart way. Further, we arrive at the notion of the Internet of Renewable Energy (IoRe) system that is able to gather only renewable electricity for the support of the grid.

In developing countries, which do not have yet implemented the high-end energy infrastructure, new technologies such as smart grid systems and IoT, demand response can become very popular (Hanger et al., 2016; Gavurova et al., 2020).

Aggregator models, on technical aspects could significantly differ, but their objectives are to simplify the participation in demand response of individual users, by measuring their real consumption against their forecasted consumption. A usual practice is to meter consumers' energy consumption that is usually made through a smart meter, whether it is a building or a household (Mahmoudi et al., 2017; Grishnova et al., 2021).

One recent study describes an alternative to smart metering, as how IoT technologies can be used for metering the consumption of individual devices. These technologies can help end consumers with an easy way to be able to take part in demand response programs. IoT can be a possible alternative to sophisticated metering infrastructure in several developing countries. This 
is also because of smaller costs of implementation and better scaling. It is expected to reduce the complexity of business models in a more distributed and decentralized system. Beyond that IoT makes the required investments for demand response to be cheaper. In addition, it provides all necessary intelligence needed for such a program. The IoT approach can offer significant market participation as these days smart plugs have become commonplace and can already be found in many consumers' homes and can be used to perform the most primary form of demand response (Radenkovic et al., 2020).

Summarizing this chapter, our research analyzes how Aggregators' roles and responsibilities in DR programs are described in the scientific literature. We also researched how Demand Response through Aggregators can be utilized in countries which at this moment lack the high-end energy infrastructure and whose grids are not well equipped with new generation of smart meters. In these countries a viable solution can be the adoption of IoT in the process of electricity supply. Further, our research consists in the analysis pointing out in which way end consumers could be attracted to DR programs through an Aggregator.

\section{Methodology}

The main objective is to determine the degree to which consumers agree to work with an Aggregator to implement demand response. The survey method was used for collecting data, from experts that operate in different fields related to energy trading, supply, generation and distribution. The subjects work in the energy sector and their occupations are traders, sales agents, supply and sale directors, portfolio managers, analysts, experts from innovation department, journalist, university professors, advisors to CEO and company owners, subjects located in Romania, Hungary and Serbia.

The previous research objective was to identify and improve business models in energy trading in the Digital Era. We had analysed and described main innovations in the field, through which the final consumers are attracted to energy trading on web platforms or mobile applications. In addition, through these they can properly control their electric appliances and self-generation units in their homes.

For this research our hypothesis was that end consumers do not want to work with an Aggregator to implement demand response. The questionnaire contains 10 questions about the subjects' demographic data and 13 questions (grouped in four questions) about the Aggregator and services offered by this. This was made through Likert scale survey questions.

Through these questionnaires at first, we wanted to research and find out what the subjects' knowledge level and attitude towards Aggregator is. Answer options for the level of knowledge were very low, relatively low, average, high and very high. Regarding the attitude towards the Aggregator, response options were as follows: strongly oppose it, oppose it, they would accept with reservations a contract with an Aggregator and they want to sign a contract with an Aggregator. Further, our research analyses those elements which are to the liking of consumers and through which an Aggregator could attract end consumers to its portfolio, represented in matrix questions. We wanted to find out which of the following services are mostly preferred by clients, when it comes to choosing to work with an Aggregator, as technical and IT support, specific legal support in regards to electricity supply contracts. Furthermore, we received information regarding repair and maintenance service of electrical household appliances, electrician service (e.g. electrical installations and lighting), home security and protection service and home insurance in case of damage and burglary. Additionally, we enquired about their interest in an Aggregator in case it is offering solutions and equipment for smart home and home renewable generation, as well 
as broadband internet access. Response variants were as follows very disinterested, disinterested, neutral interested and very interested. The last question was about what amount should be the level of incentive, in percentage from current bill value, in case the Aggregator could directly control some electrical equipment only by prior approval or through the type of contract or subscription. This was a multiple-choice question with the response variants as follows: less than $3 \%$, between $3 \%-10 \%$, between $10 \%-20 \%$ and more than $20 \%$.

Regarding the general demographic information about the subjects, we were interested in gender, age, in their monthly average electricity consumption, annual household income and what percentage of total income is spent on electricity and gas bills. In addition, respondents were asked about the place of living. If the respondents are living in a city, small city or in the countryside, as well if they live in a flat or a house and if this is rented or owned. Competencies in the energy sector and the highest level of education also was asked in the questionnaire.

\section{Results and discussions}

The interviewed subjects work in the energy sector and they are located in Romania, Hungary and Serbia. Their knowledge in the field is above average and they understand how the process of electricity generation, distribution and supply works. In addition, they are already informed about flexible contracts and Demand Response, and also have above basic knowledge of electricity supply contracts. In many developed countries, flexible contracts, Demand Response and Aggregators, in one form or another, are already utilized to some extent, and the vast majority of end consumers understand these concepts better.

The survey involved 63 respondents. Their demographic data presented in Table 1, as well data regarding electricity consumption and households incomes in Table 2.

Table 1. Subjects' general demographic data

\begin{tabular}{|c|c|c|c|c|}
\hline Category & Variable & Value & Frequency & $\%$ \\
\hline \multirow[t]{14}{*}{ General demographic data } & gender & male & 53 & $84 \%$ \\
\hline & & female & 9 & $14 \%$ \\
\hline & & preferred not to answer & 1 & $2 \%$ \\
\hline & age & $0-30$ & 3 & $5 \%$ \\
\hline & & $30-40$ & 41 & $66 \%$ \\
\hline & & $41-50$ & 17 & $27 \%$ \\
\hline & & $50+$ & 1 & $2 \%$ \\
\hline & living in a city or countryside & city & 50 & $79 \%$ \\
\hline & & small city & 12 & $19 \%$ \\
\hline & & country side & 1 & $2 \%$ \\
\hline & living in a house or in a flat & house & 18 & $29 \%$ \\
\hline & & flat & 44 & $71 \%$ \\
\hline & the property owned or rented & owned & 51 & $82 \%$ \\
\hline & & rented & 11 & $18 \%$ \\
\hline
\end{tabular}

Source: Authors' own research.

Table 2. Subjects' incomes and electricity consumption

DOI: $10.2478 /$ picbe-2021-0044, pp. 480-493, ISSN 2558-9652 |

Proceedings of the $15^{\text {th }}$ International Conference on Business Excellence 2021 


\begin{tabular}{|l|l|l|l|l|}
\hline \multicolumn{1}{|c|}{ Category } & \multicolumn{1}{|c|}{ Variable } & \multicolumn{1}{c|}{ Value } & \multicolumn{1}{c|}{ Frequency } & \multicolumn{1}{c|}{$\%$} \\
\hline $\begin{array}{l}\text { Incomes and electricity } \\
\text { consumption }\end{array}$ & annual household income & less than $€ 15000$ & 5 & $4 \%$ \\
\hline & & $€ 15000-25000$ & 33 & $26 \%$ \\
\hline & & $€ 25000-35000$ & 45 & $36 \%$ \\
\hline & & more than $€ 35000$ & 7 & $6 \%$ \\
\hline & & prefer not to answer & 35 & $28 \%$ \\
\hline & $\begin{array}{l}\text { monthly average electricity } \\
\text { consumption }\end{array}$ & $0-150 \mathrm{kWh}$ & 11 & $17 \%$ \\
\hline & & $150-300 \mathrm{KWh}$ & 36 & $57 \%$ \\
\hline & & $300-450 \mathrm{KWh}$ & 14 & $22 \%$ \\
\hline & & $>450 \mathrm{KWh} / \mathrm{month}$ & 2 & $3 \%$ \\
\hline & $\begin{array}{l}\text { household expenditure on } \\
\text { electricity and gas vs. total } \\
\text { incomes (\%) }\end{array}$ & less than 3\% & 42 & $67 \%$ \\
\hline & & between 3\%-6\% & 14 & $22 \%$ \\
\hline & & between 6\%-10\% & 5 & $8 \%$ \\
\hline & & more than $10 \%$ & 2 & $3 \%$ \\
\hline
\end{tabular}

PICBE |

In Table 3. from below can be found information related to subjects' competencies in the energy sector and the highest level of education:

Table 3. Subjects' competencies in the energy sector and level of education

\begin{tabular}{|l|l|l|l|l|}
\hline \multicolumn{1}{|c|}{ Category } & \multicolumn{1}{|c|}{ Variable } & \multicolumn{1}{c|}{ Value } & \multicolumn{1}{c|}{ Frequency } & \multicolumn{1}{c|}{$\%$} \\
\hline $\begin{array}{l}\text { Competencies and level of } \\
\text { education }\end{array}$ & $\begin{array}{l}\text { competencies in the energy } \\
\text { sector }\end{array}$ & less than 2 years & 2 & $3 \%$ \\
\hline & & $2-5$ years & 7 & $11 \%$ \\
\hline & & $5-10$ years & 21 & $33 \%$ \\
\hline & more than 10 years & 33 & $52 \%$ \\
\hline & $\begin{array}{l}\text { highest degree or level of } \\
\text { education }\end{array}$ & High School & 1 & $2 \%$ \\
\hline & & Bachelor's Degree & 20 & $32 \%$ \\
\hline & & Master's Degree & 41 & $66 \%$ \\
\hline & & Ph.D. & 0 & $0 \%$ \\
\hline
\end{tabular}

Source: Authors' own research.

Regarding the EU28 states, in 2019 more than half of the Member States have reached the $10 \%$ rate concerning the installation of electricity smart meters. Seven out of these countries already reached $80 \%$, or even finished, as Sweden, Finland, Italy, Estonia, Malta, Spain and Denmark (European Commission, 2019). In Finland all suppliers offer dynamic pricing contracts and they have very developed smart meter infrastructure. According to the above mentioned, 11\% of consumers already have contracts with hourly prices linked to the day-ahead market. Explicit utilization is also available, through 20 Aggregators both suppliers and independent, so clients are paid for the generation provided to the grid and for flexibility (smarten.eu, 2020). 
In our questionnaire we wanted to find out what is the subjects' level of knowledge about Aggregator. According to responses 16\% have very high, 19\% have high, $41 \%$ have average, $11 \%$ relatively low and $13 \%$ have very low level of knowledge. We observe that $76 \%$ of respondents have average or above average level of knowledge about Aggregator, a fact that enforces further results in our study. Results represented below in Figure 2:

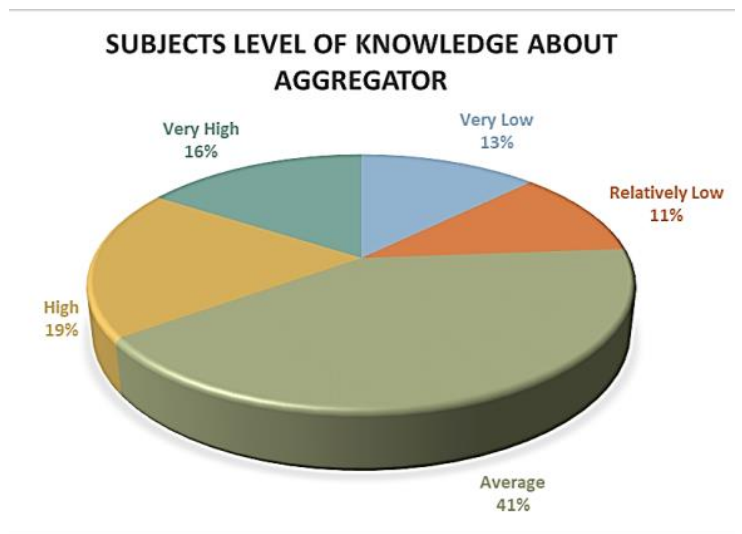

Figure 2. Subjects level of knowledge about Aggregator Source: Authors' own research.

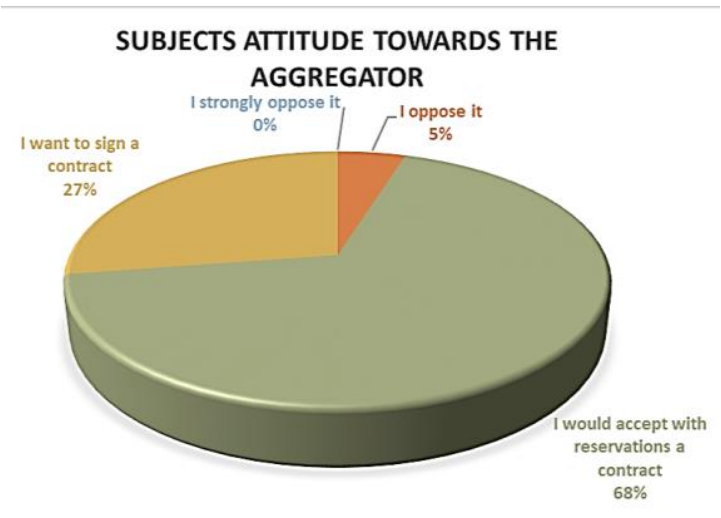

Figure 3. Subjects attitude towards the Aggregator Source: Authors' own research.

Current research started from the hypotheses that end consumers do not want to work with an Aggregator to implement Demand Response. In order to research if our hypothesis was right, subjects were asked about their attitude towards the Aggregator. The results show that $68 \%$ of subjects would accept with reservation a contract with an Aggregator and 27\% would like to sign a contract with an Aggregator. Only 5\% of subjects oppose and none of the subjects strongly oppose Aggregators. We can affirm that $95 \%$ of subjects want to work with an Aggregator to implement demand response, disproving our hypotheses that end consumers do not want to work with an Aggregator to implement demand response. Detailed results are represented in Figure 3 above.

In previous chapters we mentioned a recent study about how IoT technologies can be utilized on metering the consumption of individual devices as an alternative to smart metering and to sophisticated metering infrastructure. One part of this paper was analysing the trust in the service operator. For the DR Aggregator three possibilities of organization type were valued as follows, when the Aggregator is a non-profit organization, as a profit organization or as a public enterprise. The results indicate that respondents have the highest trust in the operator as a public enterprise, followed by profit organization and the least confidence when the operator is a non-profit organization (Radenkovic et al., 2020).

In our research, we found that end consumers are mostly interested in information and updates about their own renewable investments, $54 \%$ are interested and $28 \%$ are very interested in new solutions and equipment for smart homes, $55 \%$ are interested and $21 \%$ are very interested. In qualitative technical and IT support, 52\% are interested and 18\% are very interested. In Figure 4. below you can find a more detailed presentation of the obtained results: 


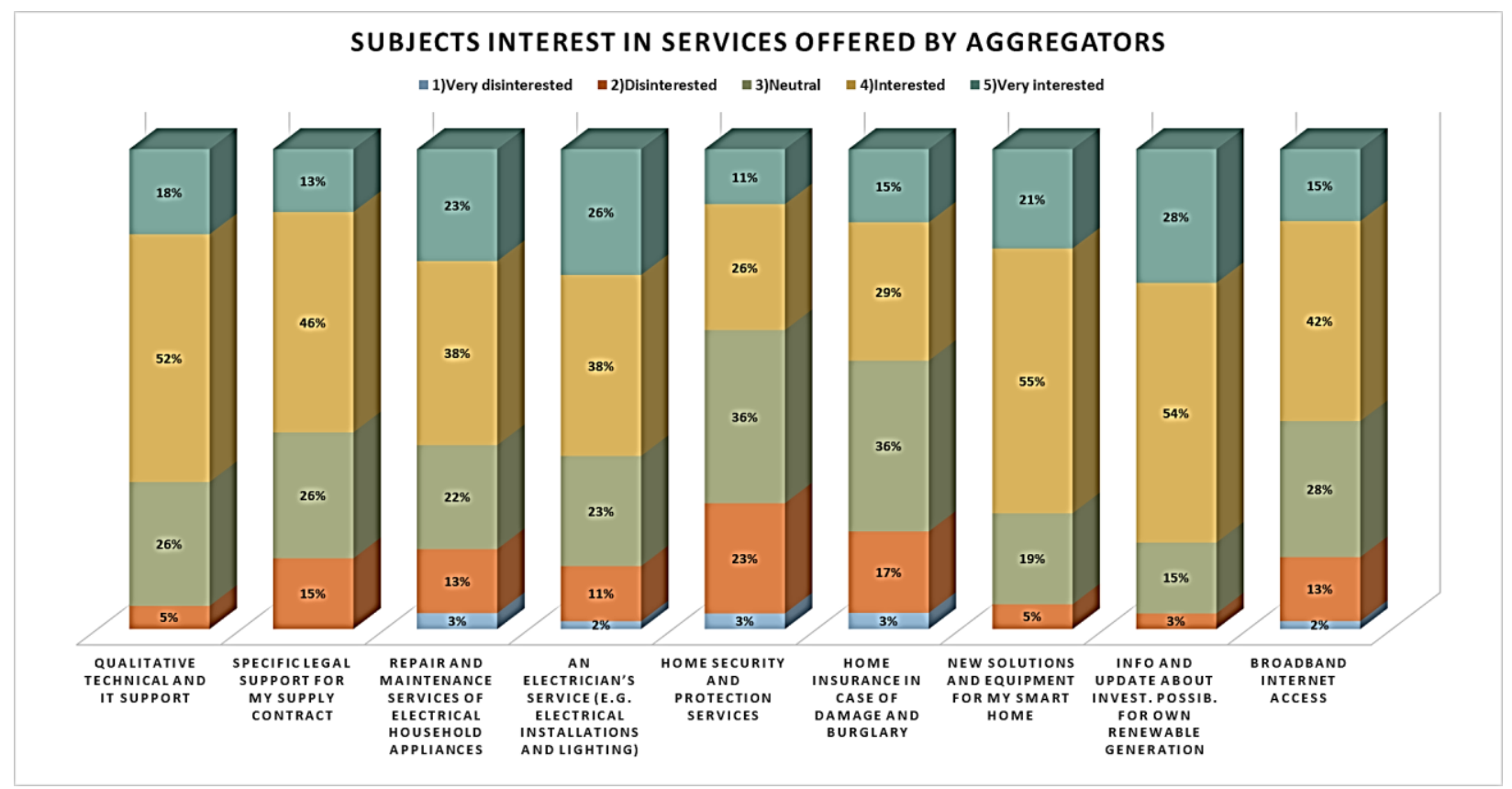

Figure 4. Subjects interest in services offered by Aggregators

Source: Authors' own research.

From the research, we found that in the case of prior approval $38 \%$ of subjects said that the level should be between $10 \%-20 \%$ and $29 \%$ of subjects said that the level has to be more than $20 \%$. In the second case, when the electrical equipment can be controlled by the type of contract or subscription $39 \%$ of subjects said that the level has to be more than $20 \%$ and $32 \%$ said that the level of incentive should be between $10 \%-20 \%$ of their current electricity bill. Detailed results for both cases can be found below in Figure 5:

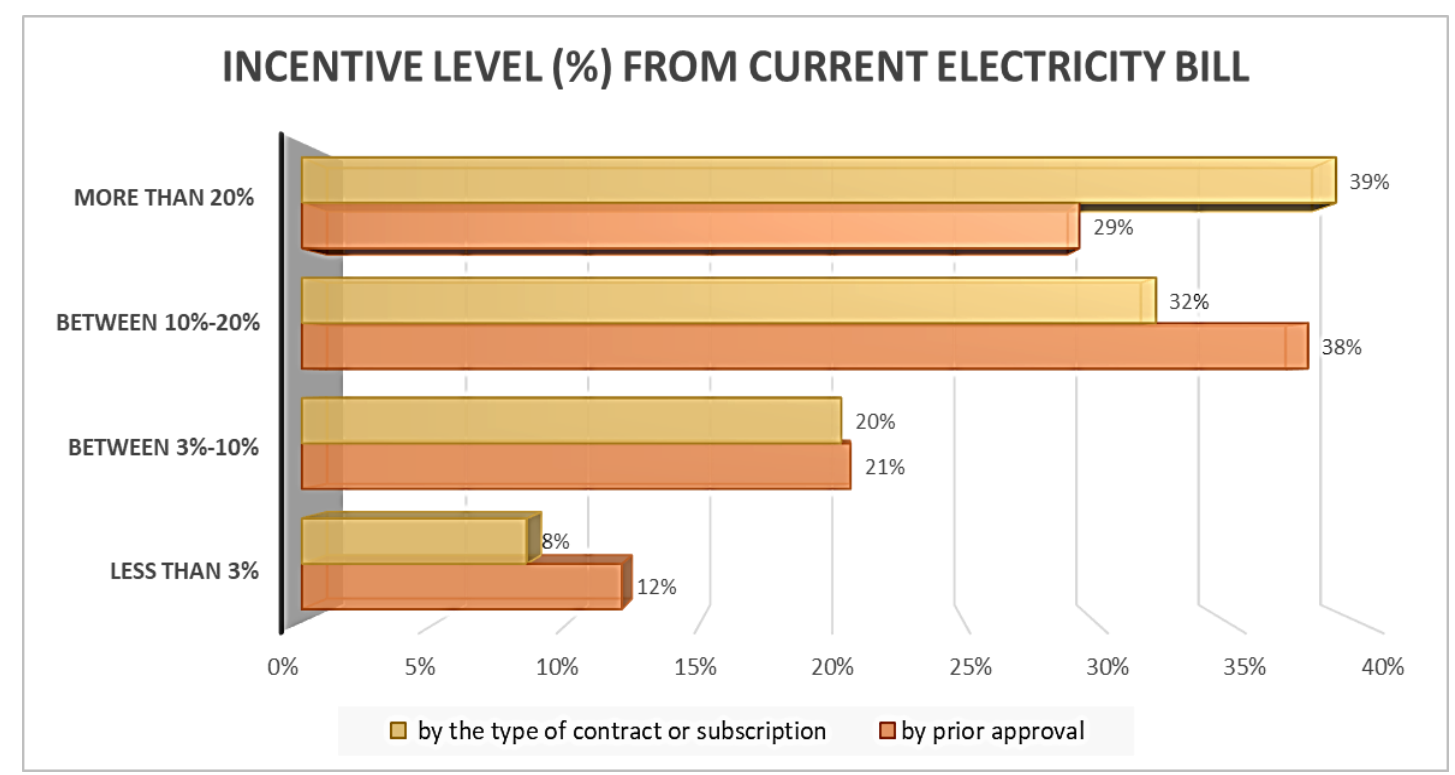

Figure 5. Incentive level (\%) for direct control of electric appliances

Source: Authors' own research. 
Analysing with One-Way ANOVA dependent list level of knowledge about Aggregators with the factor level of education we obtain the following results in Table 4, Table 5 and Table 6:

Table 4. One-Way ANOVA Descriptive

(95\% Confidence Interval for Mean)

\begin{tabular}{|l|l|l|l|l|l|l|l|l|l|}
\hline $\begin{array}{l}\text { My level of } \\
\text { knowledge about } \\
\text { Aggregators is }\end{array}$ & N & Mean & $\begin{array}{l}\text { Std. } \\
\text { Deviation }\end{array}$ & $\begin{array}{l}\text { Std. } \\
\text { Error }\end{array}$ & $\begin{array}{l}\text { Lower } \\
\text { Bound }\end{array}$ & $\begin{array}{l}\text { Upper } \\
\text { Bound }\end{array}$ & Minimum & Maximum & $\begin{array}{l}\text { Between- } \\
\text { Component } \\
\text { Variance }\end{array}$ \\
\hline High School & 1 & 3 & - & $\cdot$ & $\cdot$ & & 3 & 3 & \\
\hline Bachelor's Degree & 20 & 3,05 & 1,234 & 0,276 & 2,47 & 3,63 & 1 & 5 & \\
\hline Master's Degree & 42 & 3,19 & 1,215 & 0,187 & 2,81 & 3,57 & 1 & 5 & \\
\hline Total & 63 & 3,14 & 1,203 & 0,152 & 2,84 & 3,45 & 1 & 5 & \\
\hline Model Fixed Effects & & & 1,221 & 0,154 & 2,84 & 3,45 & & & \\
\hline
\end{tabular}

PICBE |

Table 5. Tests of Homogeneity of Variances

My level of knowledge about Aggregators is (level of education)

\begin{tabular}{|c|c|c|c|c|}
\hline & Levene Statistic & df1 & df 2 & Sig. \\
\hline Based on Mean & 0,143 & 1 & 60 & 0,706 \\
\hline Based on Median & 0,058 & 1 & 60 & 0,811 \\
\hline Based Median and with adjusted df & 0,058 & 1 & 59,778 & 0,811 \\
\hline Based on trimmed mean & 0,156 & 1 & 60 & 0,695 \\
\hline
\end{tabular}

Source: Authors' own research.

Table 6. ANOVA

\begin{tabular}{|l|l|l|l|l|l|}
\hline $\begin{array}{l}\text { My level of knowledge about Aggregators is } \\
\text { (level of education) }\end{array}$ & $\begin{array}{l}\text { Sum of } \\
\text { Squares }\end{array}$ & df & Mean Square & F & Sig. \\
\hline Between Groups & 0,288 & 2 & 0,144 & 0,097 & 0,908 \\
\hline Within Groups & 89,426 & 60 & 1,49 & & \\
\hline Total & 89,714 & 62 & & & \\
\hline
\end{tabular}

Source: Authors' own research.

Analysing with One-Way ANOVA dependent list attitude towards the Aggregator with the factor competencies in the energy sector we obtain the following results in Table 7, Table 8 and Table 9:

Table 7. One-Way ANOVA Descriptives (95\% Confidence Interval for Mean)

\begin{tabular}{|l|l|l|l|l|l|l|l|l|l|}
\hline $\begin{array}{l}\text { My attitude towards } \\
\text { the Aggregator is }\end{array}$ & $\mathbf{N}$ & Mean & $\begin{array}{l}\text { Std. } \\
\text { Deviation }\end{array}$ & $\begin{array}{l}\text { Std. } \\
\text { Error }\end{array}$ & $\begin{array}{l}\text { Lower } \\
\text { Bound }\end{array}$ & $\begin{array}{l}\text { Upper } \\
\text { Bound }\end{array}$ & Minimum & Maximum & $\begin{array}{l}\text { Between- } \\
\text { Component } \\
\text { Variance }\end{array}$ \\
\hline less than 2 years & 2 & 3 & 0 & 0 & 3 & 3 & 3 & 3 & \\
\hline 2-5 years & 7 & 3,14 & 0,378 & 0,143 & 2,79 & 3,49 & 3 & 4 & \\
\hline 5-10 years & 21 & 3,24 & 0,436 & 0,095 & 3,04 & 3,44 & 3 & 4 & 4 \\
\hline more than 10 years & 33 & 3,24 & 0,614 & 0,107 & 3,02 & 3,46 & 2 & & \\
\hline Total & 63 & 3,22 & 0,522 & 0,066 & 3,09 & 3,35 & 2 & & \\
\hline Model Fixed Effects & & & 0,532 & 0,067 & 3,09 & 3,36 & & & \\
\hline
\end{tabular}


Table 8. Tests of Homogeneity of Variances

\begin{tabular}{|l|l|l|l|l|l|}
\cline { 2 - 6 } \multicolumn{2}{c|}{} & Levene Statistic & df1 & df2 & Sig. \\
\hline \multirow{3}{*}{$\begin{array}{l}\text { My attitude towards the } \\
\begin{array}{l}\text { Aggregator is (competencies in } \\
\text { the energy sector) }\end{array}\end{array}$} & 3,344 & 3 & 59 & 0,025 \\
\cline { 2 - 6 } & Based on Mean & 1,427 & 3 & 59 & 0,244 \\
\cline { 2 - 6 } & Based on Median & 1,427 & 3 & 56,274 & 0,244 \\
\cline { 2 - 6 } & Based Median and with adjusted df & 3,926 & 59 & 0,013 \\
\cline { 2 - 5 } & Based on trimmed mean & \multicolumn{2}{|c}{ Source: Authors' own research. }
\end{tabular}

Table 9. ANOVA

\begin{tabular}{|l|l|l|l|l|l|}
\hline $\begin{array}{l}\text { My attitude towards the Aggregator is (competencies in } \\
\text { the energy sector) }\end{array}$ & $\begin{array}{l}\text { Sum of } \\
\text { Squares }\end{array}$ & df & Mean Square & F & Sig. \\
\hline Between Groups & 0,162 & 3 & 0,054 & 0,19 & 0,903 \\
\hline Within Groups & 16,727 & 59 & 0,284 & & \\
\hline Total & 16,889 & 62 & & & \\
\hline
\end{tabular}

Source: Authors' own research.

After performing the test with our data, values of the F-test $(0,097$ and 0,19$)$ and $p$ $(0,908$ and 0,903$)$ were obtained. As can be judged from the value of $p$, the evidence is overwhelming that the variants are homogeneous. Data was processed with Ms Office Professional Plus 2016 and IBM SPSS Statistics for Windows, Version 27.0.1.0.

\section{Conclusion}

As we have mentioned before, the interviewed subjects work in the energy sector. Because of this, their knowledge in the researched field is above average and they understand well how the processes work. Their answers are objective. Subjects from different areas of activity that have nothing in common with the energy sector can have wrong assumptions about the matter.

We also have to bear in mind that the questionnaire offers some brief information and explanation about the researched activity in case the subject is not sure about the expression or the process from behind.

The results show that end consumers' level of knowledge on Aggregator is high. Regarding their attitude towards the Aggregator, the big majority would accept a contract with reservation with an Aggregator or they are ready to sign a contract. We can assume that through good information and communication towards consumers on different communication channels, they can be more attracted to the utilization of described services from the moment they will be available. Education and awareness have a huge role in achieving a more rational, optimal and conscious consumption of electricity through Demand Side Management. The issue has to be raised to the level of importance and acceptance similar to what recycling of other recyclable materials have nowadays, such as paper, plastic, various metals and glass. From our research we can conclude that having a contract or subscription to an Aggregator, will be attractive to electricity prosumers and consumers, as well as will have a greater impact on energy trading and supply business models.

As we have seen, the role of an Aggregator is to collect Demand Response resources of all end consumers, accumulate the load flexibility of residential end consumers and gather small generators as virtual power plants. For usual end consumers beyond these, in order to attract them, it is necessary to offer additional attractive services. Further to the above mentioned, Aggregators 
have also a main role to communicate that through participation in these programs aids in the rational and optimal consumption of green energy and in the decrease of global warming and how can be reduced electricity generation from fossil polluting fuels. End consumers should be attracted to these programs in order to reach emissions reduction to zero and to reach total electrification from renewable energy. We must keep in mind that lack of general education, energy poverty and absence of high-end energy infrastructure, or at least investments and continuous developments, remain a big obstacle against a fast integration of described business models.

Future research will be oriented toward the acceptance and attitude regarding flexible electricity contracts and Demand Response in the Central and South-Eastern Europe region, without the involvement of an Aggregator.

\section{References}

EFET (2012). Illustration of the developing EU electricity market, Adapted from Towards a single European energy market, EFET 15 years Edition, page 4, Retrieved from https://www.efet .org/Files/Documents/Energy\%20Background/Highlights-II-Final.pdf, accessed on $15^{\text {th }}$ of November 2019.

European Commission (2020). Benchmarking smart metering deployment in the EU-28, Final Report, 2020. Retrieved from https://op.europa.eu/en/publication-detail/-/publication/ b397ef73-698f-11ea-b735-01 aa75ed71a1, accessed on 20 ${ }^{\text {th }}$ of December 2020.

European Commission (2016). Demand Response status in EU Member States, 2016. Retrieved from https://ec.europa.eu/jrc/en/publication/eur-scientific-and-technical-research-reports/ demand-response-status-eu-member-states, accessed on $20^{\text {th }}$ of December 2020.

European Commission (2009). Third energy package, Retrieved from https://ec.europa.eu/ energy/en/topics/markets-and-consumers/market-legislation/third-energy-package, accessed on 11th of December 2020.

European Parliament (2020). Fact Sheets on the European Union, Internal energy market, November 2020, Retrieved from http://www.europarl.europa.eu/factsheets/en/sheet/45/ internal-energy-market, accessed on 11 st of December 2020.

Gavurova, B., Cepel, M., Belas, J., and Dvorsky, J. (2020). "Strategic Management in SMEs and Its Significance for Enhancing the Competitiveness in the V4 Countries - A Comparative Analysis", Management \& Marketing. Challenges for the Knowledge Society, 15(4), 557-569, DOI: 10.2478/mmcks-2020-0032.

Grishnova, O., Bereziuk, K., Bilan, Y. (2021). "Evaluation of the level of corporate social responsibility of Ukrainian nuclear energy producers", Management \& Marketing. Challenges for the Knowledge Society, 16(2), 152-166, DOI: 10.2478/mmcks-2021-0010.

Hanger, S., Komendantova, N., Schinke, B., Zejli, D., Ihlal, A., Patt, A. (2016). Community acceptance of large-scale solar energy installations in developing countries: evidence from Morocco, Energy Res. Soc. Sci. 14, 80-89.

International Energy Agency (2017). Digitalisation and Energy, November 2017, Retrieved from https://www.iea.org/reports/digitalisation-and-energy, accessed on $13^{\text {rd }}$ of March 2020.

Jordehi, A.R. (2019). Optimization of demand response in electric power systems, a review, Renewable and Sustainable Energy Reviews Journal, Volume 103, 308-319.

Lu, X, Li, K, Xu, H, Wang, F., Zhou, Z., Zhang, Y. (2020). Fundamentals and business model for resource aggregator of demand response in electricity markets, 2020, Energy, 204, 117885. 
Mahmoudi, N., Heydarian-Forushani, E., Shafie-khah, M., Saha, T.K., Golshan, M.E.H., Siano, P. (2017). A bottom-up approach for demand response aggregators' participation in electricity markets. Electr. Power Syst. Res. 143, 121-129.

Radenković, M., Bogdanović, Z., Despotović-Zrakić, M., Labus, A., Lazarević, S. (2020). Assessing consumer readiness for participation in IoT-based demand response business models, Technological Forecasting and Social Change, Volume 150, January 2020, 119715.

smartEn (2020). The smarten Map PROSUMERS 2020, Retrieved from https://smarten.eu/wpcontent/uploads/2020/12/the_smarten_map_2020_DIGITAL.pdf， accessed on $10^{\text {th }}$ of December 2020.

Tsao, Y., Thanh, V., Wu, Q. (2021). Sustainable microgrid design considering blockchain technology for realtime price-based demand response programs, Electrical Power and Energy Systems, 125, 106418.

U.S. Department of Commerce (2019). Internet of Things, Retrieved from https://www.commerce. gov/news/blog/2019/10/internet-things, accessed on $9^{\text {th }}$ of January 2021.

Vrânceanu, D.M., Țuclea, C.E., Țigu, G. (2020). "Price search behaviour in digital markets - A perspective from Romania", Management \& Marketing, Challenges for the Knowledge Society, 15(2), 219-235, DOI: 10.2478/mmcks-2020-0014.

Zhang, C., Wu, J., Zhou, Y., Cheng, M., Long, C. (2018). Peer-to-Peer energy trading in a Microgrid, Applied Energy, Volume 220, 15 June 2018, Pages 1-12. 